\title{
Effects of UVA and its simultaneous action with blue light on the growth and phototropism of cress leaves under various gravity conditions
}

\section{Regina Losinska-Sičiūnienė $\dot{ }^{\star}$,}

Ramunè Stanevičienè,

Danguolè Švegždienè

Nature Research Centre,

Akademijos 2,

Vilnius 08412, Lithuania
The gravity of the Earth $(1 g)$ and phototropic active components of the light spectrum are the stimuli regulating the directional growth of plants. In this study, the role of combined light and gravity effects on plant leaves (Lepidium sativum L.) was tested. Treatment with UVA $(370 \mathrm{~nm})$ or UVA combined with blue light together with the gravity in the slow clinostat (clinorotated $3 \mathrm{rpm}$ ), or Earth's gravity (1g), was applied. A custom-built clinostat with LEDs allowed unidirectional illumination of cress leaves. UVA or UVA with blue light was directed laterally at cress leaves for a $3 \mathrm{~h}$ exposure. Responses of cotyledons and true leaves, both under $1 g$ and clinorotation conditions, were compared. The obtained data show that UVA $(370 \mathrm{~nm})$ suppresses the elongation of cotyledons and true leaves under changed gravity of the Earth. Clinorotation suppresses the growth of cotyledons but not of the true leaves under UVA with blue light. Comparison of leaf phototropism induced by different illuminations under $1 g$ and changed gravity conditions revealed that phototropism was induced by clinorotation but suppressed by Earth's gravity. Phototropic responses of true leaves under clinorotation were stronger than those of cotyledons.

Keywords: Earth's gravity, clinorotation, ultraviolet A, leaf, tropisms

\section{INTRODUCTION}

Constantly responding and adjusting to environment-dependent responses, plants have developed plasticity of growth (Trewavas, 2005). Gravity and light are two ecological factors that substantially determine the peculiarities of plant growth, tropisms, spatial orientation, and initial adaptation to the alterations of the environment. The direction and magnitude of gravity as well as the direction,

\footnotetext{
* Corresponding author. Email: regina.ska@gmail.com
}

intensity and spectral components of light greatly affect the directional growth of terrestrial plants (Bastien et al., 2015; Takemura et al., 2017). Therefore, in the environment of Earth's gravity ( $1 g)$, it is difficult to distinguish whether gravity, light, or both stimuli cause plant responses. To distinguish between the effects of these stimuli, a clinostat or a random positioning machine may be used (Hoson et al., 1997; Kraft et al., 2000). Slow clinorotation $(3 \mathrm{rpm})$ is one of the best modes to study the influence of omnilateral gravistimulation on plant reactions to monochromatic light. It is 
evident that plants sustain a stress under gravity alterations and undergo adaptation the impact of which can disturb the usual chain of growth processes (Kittang et al., 2004; Sohet et al., 2011). Under altered gravity conditions, light can play a crucial role in the optimization of growth through phototropism, controlling the pathways to achieve adaptive growth. Furthermore, phototropic responses of seedlings to blue, red, and far-red light are strengthened under altered gravity conditions (Vitha et al., 2000; Corell, Kiss, 2002; Kumar et al., 2008; Kiss et al., 2011; Raklevičienė et al., 2011). Blue-lightbased phototropism of Arabidopsis hypocotyls was stronger in real microgravity as compared with phototropism in the $1 g$ environment $(\mathrm{Ku}-$ mar et al., 2008). Interestingly, hypocotyls of seedlings developed in microgravity (changed gravity conditions) show positive phototropic responses to red light; however, responses of hypocotyls grown at $1 g$ in a space centrifuge or on the ground were not apparent (Millar et al., 2010). These findings imply that alterations of gravity conditions may act as a significant factor in plant responses to light. Ultraviolet A is also involved in the regulation of numerous growth processes, including germination, vegetative growth, organogenesis, phototropisms, circadian rhythms, and flowering induction (Maffei et al., 1999; Jayakumar et al., 2004; Krizek, 2004; Sarghein et al., 2008; Victório et al., 2011). Current data suggest that blue light and gravity play major roles in the control of seed germination (Vitha et al., 2000). As far as we are aware, knowledge of the events related to leaf responses to clinorotation under UVA or its simultaneous action with blue light is sparse. Taking into consideration the fact that light and gravity are stimuli regulating the directional growth of plants, we suppose that a unidirectional lateral short-term exposure of the basal part of leaf petioles to ultraviolet $\mathrm{A}(370 \mathrm{~nm})$ and its simultaneous action with blue $(450 \mathrm{~nm})$ light might modulate slow clinorotation $(3 \mathrm{rpm})$ effects on the growth of cress leaves. The main objective of this study was to investigate phototropism and growth of leaves to the tested illuminations under simulated microgravity conditions.

\section{MATERIALS AND METHODS}

\section{Plant materials and light treatments}

The experiments were performed using nineday-old cress (Lepidium sativum L.). Seedlings, germinated for one day in Petri dishes, were planted in the centre of glass tubes (diameter $3.0 \mathrm{~cm}$, height $4.5 \mathrm{~cm}$ ) on rockwool (Pargro, the Netherlands) moistened with 1/2 MS medium. Cress seedlings grew in stationary vertical glass tubes illuminated by fluorescent lamps OSRAM FLUORA (L 36 W/77, density $240 \mu \mathrm{mol} \mathrm{m} \mathrm{m}^{-2} \mathrm{~s}^{-1}$ ) for 12 hours of light/dark photoperiod. Then, the glass tubes with plants were placed into cultivation holders. One set of holders was attached to the horizontal axes of the clinostat and clinorotated at $3 \mathrm{rpm}$, while the other set remained vertical as a control variant $(1 g)$. Before the exposure to the test light, both sets of plants were cultivated for 20 hours in the dark for diminishing white light effects (Allen et al., 2006). In order to test the effects of clinorotation (CR) on the leaves under UVA and simultaneously with blue light ( $\mathrm{UVA}+\mathrm{BL})$, a custom-built lighting system consisting of autonomous illumination units for each cultivation holder was produced (Fig. 1a). Each unit was composed of monochromatic UVA (Optosource, Ultra-Violet 260019, $370 \mathrm{~nm}$ ) and blue (BL, Epitex, L450-06, $450 \mathrm{~nm}$ ) emitting diodes. BL intensity was measured by a photoradiometer (HD2102.1, Delta OHM, Italy). UVA irradiance was recorded by a VLX-3W radiometer (Vilber Lourmat, France). Photon flux density of UVA amounted to approximately $13 \mu \mathrm{mol} \mathrm{m} \mathrm{m}^{-2} \mathrm{~s}^{-1}$ and that of BL to $30 \mu \mathrm{mol} \mathrm{m} \mathrm{m}^{-2} \mathrm{~s}^{-1}$. All experiments were carried out at ambient temperature of $23 \pm 1^{\circ} \mathrm{C}$. For a three-hour exposure, light-emitting diodes were switched on without stopping CR. UV-A or UV-A+BL was applied laterally to the plants. During the experiments, the maximal distance of the leaf petioles did not exceed $3 \mathrm{~mm}$ from the longitudinal axis of the cultivation holders. Thus, the leaf petioles could be affected by the centrifugal force of $3 \times 10^{-5} \mathrm{~g}$ during $\mathrm{CR}$. Accordingly, apexes of leaf laminas were outlying 7.4-14.9 $\mathrm{mm}$ from the axis and affected by the force of $7.4 \times 10^{-5}-1.5 \times 10^{-4} \mathrm{~g}$, respectively. 


\section{Analysis of leaf positions}

Leaf positions (phototropic response) were recorded at $30 \mathrm{~min}$ intervals with digital cameras (Moticam 2000, 2300, and Sony DSLRA390L) in 2D format. Analysing each exposure period, digital leaf images were evaluated by measuring the cotyledonary petiole angle (Fig. 1a) and true leaf petioles angle with respect to the light source (Fig. 1b). The sets of the UVA variant represent 13-16 and 8-9 analysed plants, of UVA+BL $-8-9$ and 6-7 for $1 g$ and $\mathrm{CR}$, respectively.

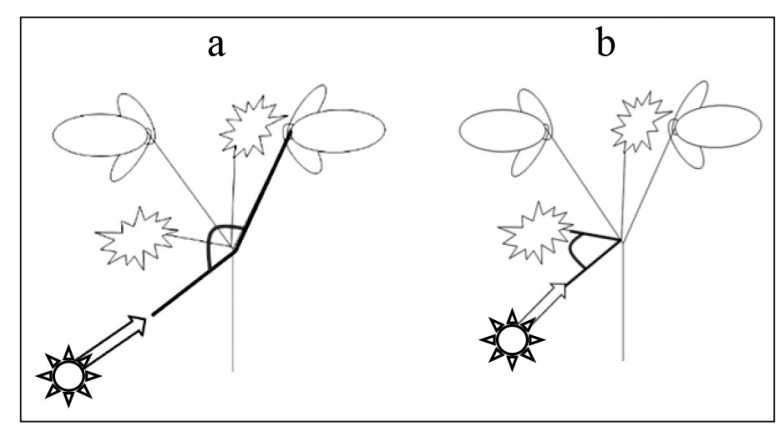

Fig. 1. Scheme for the assessment of the spatial position of the cress leaf (cotyledons (a) and true leaf (b) petiole angle with respect to the light source)

Histological analysis of leaf petioles of the cress Cotyledon and true leaf petioles were fixed with liquid chemical fixative FAS (made from formaldehyde, acetic acid, and ethanol, 1:1:18). Fixed substance was kept for four days at $+4^{\circ} \mathrm{C}$ and then washed with $70 \%$ ethanol. After this procedure, prepared samples were dehydrated and impregnated with paraffin. Impregnated petioles were cut by rotary microtome in 10-12 $\mu \mathrm{m}$ thickness sections. According to the modified methodology of the Experimental Plant Ecology Laboratory, periodic acid-Schiff reaction and safranin were used to paint longitudinal sections of petioles. Canadian balsam was used in the permanent histological preparations. For histological analysis of leaf petioles 5-7, a full version of each preparation was selected and analysed. Preparations were studied under a microscope and photographed, while digital images were analysed using Motic ImagePlus 2.0 ML and SigmaScan Pro 5 software packages.

\section{Statistical analysis}

Statistical analysis was conducted using the standard Anova package for MS Excel 7. Reported values are presented as the mean \pm standard error (SE). Each set of the experiments was repeated at least three times. The measurements of the CR leaves were compared with those of $1 g$ control (Earth's gravity). Statistical differences were determined by the Student's test at the significance level of $p \leq 0.05$.

\section{RESULTS AND DISCUSSION}

The gravity effect on plants is associated with the growth of spatial orientation - gravitropism. In real and clinoratation (simulated microgravity) conditions, plants lose vertically-oriented growth, resulting in a change in organogenesis and growth parameters (Merkys, Laurinavičius, 1990; Laurinavičius et al., 2001; Bastien et al., 2015; Takemura et al., 2017). Another important growth direction determining environmental factor is light. Phototropism is defined as plant organs or growth directed towards or against the light source. It depends on the quantitative and qualitative indicators of the light and the characteristics of the organ (plant). In the course of evolution, plants adapted to the gravitational constant and regularly changing light exposure to form sensory systems, which, at first glance and for many years, seemed not related. Establishment of direct phototropism and indirect gravitropism connection with the phytochrome activity (Correll, Kiss, 2002; Lariguet, Frankhauser, 2004, 2005; Kumar, Kiss, 2006) and a definite connection with the auxin and the transporter proteins PIN1 and PIN3 (Friml et al., 2003; Roychoudhry, 2017) opens the way to investigate the spectral light components that influence the plants on Earth's and MG conditions. Thale cress and gravitropic and phototropic mutants have proven a connection between these tropisms (Vitha et al., 2000; Corell, Kiss, 2002). It can be assumed that eliminating the gravity or during hypergravity (Takemura et al., 2017), plant growth and development can be effectively regulated by a balanced spectrum and intensity of light. However, 
results of these tests with the cress (Arabidopsis) (Millenaar et al., 2005; Stutte et al., 2006; Mano et al., 2006), rice (Oryza sativa L.), barley (Hordeum vulgare L.), and sweet potatoes (Ipomoea batatas L.) (Kitaya et al., 2001, Hua et al., 2007) are controversial and there is no clear answer about the influence of individual spectral components and the flux density on different kinds of plant growth and morphogenesis in the conditions of Earth's gravitation and real or simulated microgravity. Terrestrial plants evolved under constant $1 g$ gravity and changing light environment; therefore, their responses to gravity alterations may be modified by components of the light spectrum (Corell, Kiss, 2002; Buizer, 2007; Kiss et al., 2011; Raklevičienè et al., 2011; Klem et al., 2019).

\section{Leaf growth}

We compared the effects of microgravity simulated by slow clinorotation under UVA $(370 \mathrm{~m})$ and under simultaneous action of UVA with blue light (UVA+BL, $450 \mathrm{~nm}$ ) on cotyledons and true leaves of cress. During a 3-h exposure to UVA, clinorotation (CR) caused a substantial decrease in the elongation of cotyledons and true leaves in comparison with the growth of control plants at $1 g$ ( Table 1). However, after UVA+BL illumination, gravity-independent growth of true leaves and gravity-dependent growth of cotyledons were ascertained. In comparison with $1 g$ conditions, clinorotation promoted a radial expansion and eliminated size differences in cotyledons under both tested illuminations. However, CR under $\mathrm{UVA}+\mathrm{BL}$ resulted in a significant decrease in the length of cotyledons but not in the length of true leaves. Therefore, the area of true leaves but not of cotyledons was diminished after CR under UVA (Table 2). When UVA was applied simultaneously with BL, CR provoked an approximately $12 \%$ increment in the area of true leaves; however, it was insignificant in comparison with the area of control true leaves. Clinorotation and UVA resulted in a significant reduction of the leaf area. These findings verify

Table 1 . The length of cress leaves under clinorotation and at $1 g$ after UVA and UVA+BL illumination

\begin{tabular}{c|cc|c|c}
\hline \multirow{2}{*}{ Illumination } & \multicolumn{4}{|c}{ Length (mean \pm SE), $\mathbf{~ m m}^{\mathbf{2}}$} \\
\cline { 2 - 5 } & \multicolumn{2}{|c}{ Cotyledons } & \multicolumn{2}{c}{ True leaves } \\
\cline { 2 - 5 } & $\mathbf{1 g}$ & $\mathbf{C R}$ & $\mathbf{C R}$ \\
\hline \multirow{2}{*}{$\mathrm{UVA}$} & $26.08 \pm 0.34$ & $23.26 \pm 0.48^{*}$ & $16.30 \pm 0.33$ & $13.65 \pm 0.50^{*}$ \\
& $(21)$ & $(18)$ & $(21)$ & $(18)$ \\
\hline \multirow{2}{*}{$\mathrm{UVA}+\mathrm{BL}$} & $26.84 \pm 0.40$ & $24.36 \pm 0.32^{*}$ & $16.47 \pm 0.32$ & $16.48 \pm 0.41$ \\
& $(19)$ & $(20)$ & $(19)$ & $(20)$ \\
\hline
\end{tabular}

* - the difference between $1 \mathrm{~g}$ and clinorotation variants (CR) is significant at $p \leq 0.05$

The number of analyzed samples is given in brackets.

Table 2. Impact of clinorotation on the area of cotyledons and true leaves after illumination with UVA and UVA $+B L$

\begin{tabular}{|c|c|c|c|c|}
\hline \multirow{3}{*}{ Illumination } & \multicolumn{4}{|c|}{ Area $($ mean $\pm \mathrm{SE}), \mathrm{mm}^{2}$} \\
\hline & \multicolumn{2}{|c|}{ Cotyledons } & \multicolumn{2}{|c|}{ True leaves } \\
\hline & $1 g$ & CR & $1 g$ & CR \\
\hline UVA & $\begin{array}{c}85.70 \pm 4.14 \\
(22)\end{array}$ & $\begin{array}{c}82.25 \pm 2.46 \\
(37)\end{array}$ & $\begin{array}{c}41.36 \pm 3.71 \\
(22)\end{array}$ & $\begin{array}{c}35.24 \pm 1.47^{\star} \\
(36)\end{array}$ \\
\hline $\mathrm{UVA}+\mathrm{BL}$ & $\begin{array}{c}93.11 \pm 3.17 \\
(18)\end{array}$ & $\begin{array}{c}91.02 \pm 3.19 \\
(20)\end{array}$ & $\begin{array}{c}39.28 \pm 2.70 \\
(19)\end{array}$ & $\begin{array}{c}44.09 \pm 2.11 \\
(20)\end{array}$ \\
\hline
\end{tabular}

* - the difference between $1 g$ and CR variants is significant at $p \leq 0.05$

The number of analyzed samples is given in brackets. 
the supposition that clinorotation promotes a radial growth if one of the applied spectral components of light is blue.

It is important to have in mind that clinorotation as well as the application of UVA and blue light induce stress responses. The surface of plant leaves actively responds to alterations of gravity (Kitaya et al., 2001) and light spectrum (Lariguet, Fankhauser, 2005; Roychoudhry, 2017).

\section{The effect of UVA and UVA with blue light on the leaf phototropism}

Gravity and light-related tropisms of leaves or stem-like organs were observed in microgravity and in ground-based experiments (Corell, Kiss, 2002; Lariguet, Fankhauser, 2004, 2005; Buizer, 2007; Kiss et al., 2011). To our knowledge, numerous studies into graviresponse of the leaves of different plant species showed ambiguous results. The dynamics of the movement is then fully determined by the leaf that was inside (Kitaya et al., 2001; Stutte et al., 2006; Mano et al., 2006; Hua et al., 2007; Solheim et al., 2009; Soh et al., 2011; Bastien et al., 2015). We investigated phototropism of leaves of green plants after $24 \mathrm{~h}$ darkness period in order to eliminate the effects of white light. Phototropism of leaves was estimated by measuring the curvature of their petioles from the initial position towards light-emitting diodes. Digital image analysis showed that in microgravity (MG) conditions, when one-direction gravitropic irritation is suppressed, leaf positive phototropic response to UVA is revealed (Fig. 2a). The angle of cotyledon petioles to UV-A decreased by $2-5^{\circ}$ within $30 \mathrm{~min}$ interval in CR. Within $180 \mathrm{~min}$, the petiole angle toward the UV-A decreased to $24^{\circ}$ (Fig. 2b). Under $1 g$ conditions, the angle of cotyledon petioles with respect to the UVA source decreased only by $1-3^{\circ}$ within 30 min interval, so during the test $(180 \mathrm{~min})$ the angle decreased by $7^{\circ}$. Therefore, it can be inferred that the UVA effect is suppressed based on gravity. Under $\mathrm{CR}$, the true leaf petiole angle toward the UVA decreased by $4-5^{\circ}$ every $30 \mathrm{~min}$, and throughout the test $(180 \mathrm{~min})$ decreased by about $26^{\circ}$ (Fig. 2c). In the $1 g$, the angle between the petioles and UVA source direction decreased by $11^{\circ}$ within $180 \mathrm{~min}$. A slightly more intense decrease in the true leave petiole angle is identified

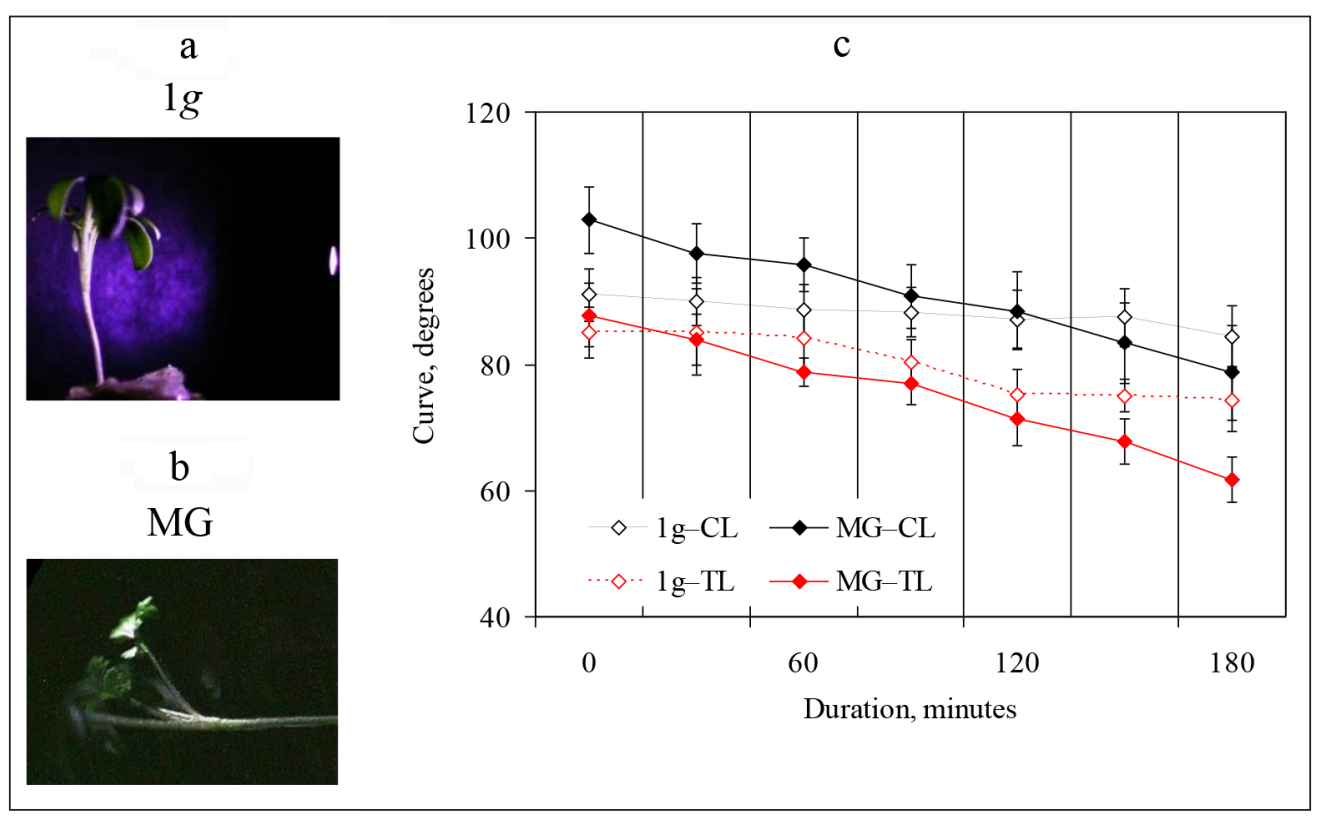

Fig. 2. Cress leaf position at the end of the test $180 \mathrm{~min}(\mathrm{a}, \mathrm{b})$ and the phototropic response of different cress leaves (cotyledons - CL and true leaf -TL) (c) with UVA radiation in simulated microgravity (MG) conditions and affected by gravity $(1 g)$. Means $( \pm S E)$ with different letters are significantly different at $p \leq 0.05$ 
between 60 to $120 \mathrm{~min}$ of the test, and the angle did not change between 120 to 180 min (Fig. 2c).

The received image analysis revealed that in the conditions of simulated MG and UVA+BL light affects leaf increase (Fig. 3a, 3b). The cotyledonary petiole angle in $M G$ conditions with respect to UVA+BL light decreased by $8^{\circ}$ within $30 \mathrm{~min}$ interval. The angle decreased during the whole test. Within $180 \mathrm{~min}$, the cotyledonary angle with the respect to the light source decreased by $32^{\circ}$ (Fig. 3c). As the decline of the angle indicates the cotyledon petiole movement towards the light source, so it can be said that in MG conditions UVA+BL phototropic lighting has a positive impact on the cotyledons. In normal gravity conditions, the UVA+BL lighting effect is almost imperceptible (Fig. 3c). With respect to UVA+BL light, the cotyledonary petiole angle was declining slightly, by $1-2^{\circ}$, within a $30 \mathrm{~min}$ interval and during the whole period of the test the angle decreased only by $8^{\circ}$ (Fig. $3 \mathrm{c}$ ). Lighting true leaf petioles with UVA+BL light under MG conditions for up to $30 \mathrm{~min}$ had a negative impact. The petiole angle to the light source has increased by $5^{\circ}$, the true leaves moved away from the light source. From 30 to
$150 \mathrm{~min}$, the petiole angle increased rapidly by $15^{\circ}$ (Fig. 3c), then the true leaves did not move and the angle did not change. In MG conditions, the petiole angle decreased by $36^{\circ}$ from the beginning of the test (Fig. $3 \mathrm{c}$ ). In $1 g$ conditions, the UVA+BL lighting effect was not as significant on true leaves as under MG conditions. For up to $30 \mathrm{~min}$ of the test, the petiole angle with respect to the light source was slightly declining, and between 60 and 120 min the angle did not change. Normal gravity suppresses UVA+BL light effect on the true leaves. From the $120 \mathrm{~min}$, a slight $3^{\circ}$ petiole angle decline with respect to the source of illumination was identified (Fig. 3c).

The phototropic movement of the petioles revealed that true leaves were more sensitive to clinorotation than cotyledons. Besides, UVA+BL stimulated positive phototropism of clinorotated leaves of both types more intensively compared with UVA. The data on tropisms of $1 g$ and clinorotated leaves show that phototropism induced by UVA in true leaves or by UVA+BL in both cotyledons and true leaves is suppressed by gravitropism.

The most common UVA radiation studied in normal gravity conditions is as attached to

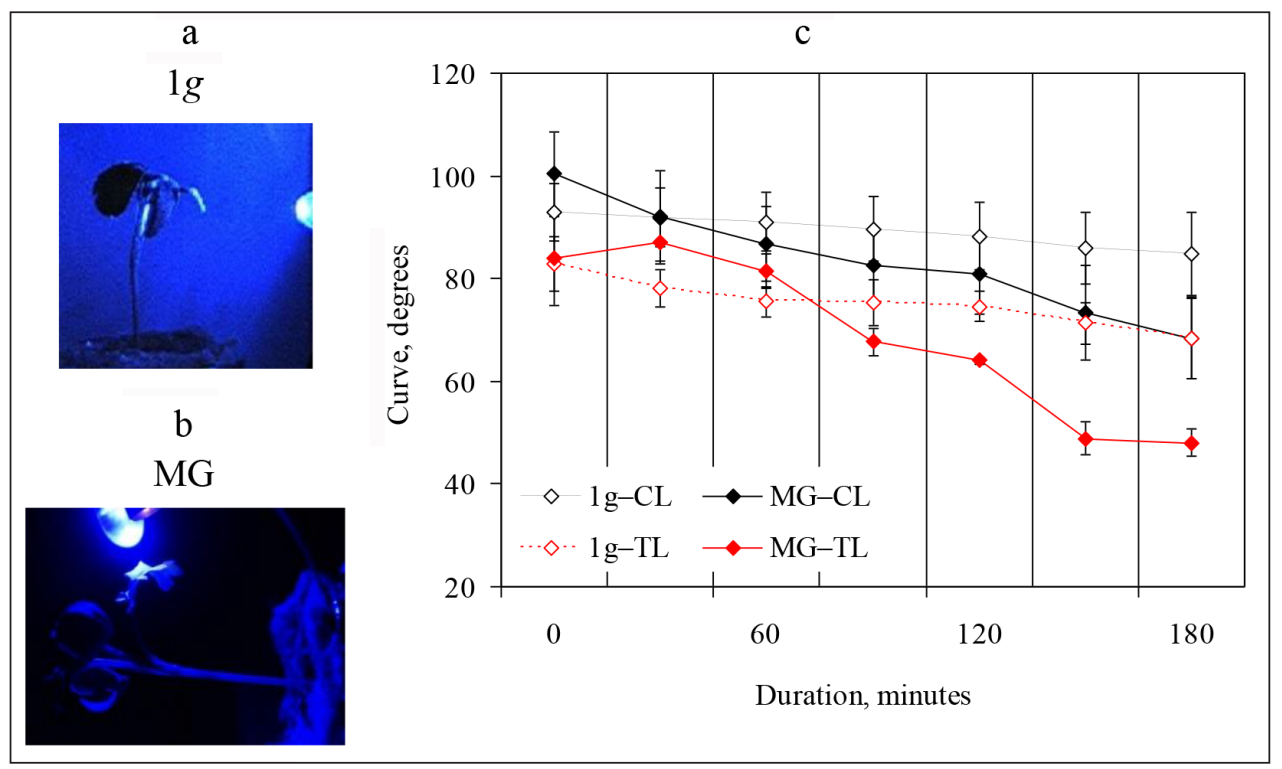

Fig. 3. Cress leaf position at the end of the test $180 \mathrm{~min}(\mathrm{a}, \mathrm{b})$ with UVA+BL light and phototropic response of different cress leaves (cotyledons - CL and true leaf - TL) in simulated microgravity $(\mathrm{MG})$ conditions and affected by gravity $(1 g)(\mathrm{c})$. Means $( \pm \mathrm{SE})$ with different letters are significantly different at $p \leq 0.05$ 
natural light. Basic blue, red and far-red light spectrum replenishment of UVA $(380 \mathrm{~nm})$ radiation stimulated the development of tomato seedlings. Such lighting influence on tomato seedlings had the highest leaf area and the shortest hypocotyls. Additional UVA radiation adversely affected all varieties of winter wheat, but stimulated the accumulation of antioxidant substances in rye, spring wheat, and barley (Urbonavičiūtè et al., 2009). UVA radiation has an antioxidant microgreens potential increasing property (Brazaityte et al., 2015). It is known that UVA radiation causes stress to plants, but smaller amounts can increase the content of photosynthetic pigments and stimulate growth (Urbonavičiūtè et al., 2007; Brazaityte et al., 2010). It is considered that UVA radiation and/or its combination with white or blue light positively influence photomorphogenesis, photosynthetic activity, and accumulation of biomass (Yayakumar et al., 2004; Maffei et al., 1999). Previous studies show that cucumber and Arabidopsis thaliana seedlings marked positive phototropism to short and long wave UV (Shinkle et al., 2004). Other authors confirm that the UVA $(320-390 \mathrm{~nm})$ and blue light (390-500 nm) affect the Arabidopsis gene expression and regulate leaf phototropism and growth in natural gravity conditions (Jenkins, 1997; Fankhauser, Chory, 1997). In the CR environment, the tropical leaf response bookmark was faster, so it can be inferred that using blue light has higher photon flux density and a balanced lighting can regulate plant growth. The assumption is that reaction of organ growth in CR depends on the development of organs and is particularly sensitive to blue light beam, which controls $0 \leq g \leq 1$ gravitational environment cultivated plant leaf tropism (Whippo, Hangarter, 2004; Kumar et al., 2008).

The statolith theory of gravisensing is based on the results of numerous studies (Yamamoto, Kiss, 2002; Kordyum et al., 2007; Scherp, Hasenstein 2007; Vitha et al., 2007). Sedimentation of amyloplasts (statoliths) in root and stem gravisensory cells (statocytes) is an integral part of graviperception and is neces- sary for the induction of gravitropic response. However, unlike the root statocyte, here the nucleus may settle with amyloplasts, and when the stem is upright, they located at the bottom of the cell (Kato et al., 2002). According to some researchers, the central vacuole plays a key role in mast gravisensing by influencing the movement of amyloplasts in endoderm cells. It is believed that during the sedimentation of amyloplasts, these interactions with the tonoplast may release ions necessary for the transmission of the gravity signal (Morita et al., 2002). It is also possible that the proteins of the amyloplast membrane interact with vacuolar tonoplast proteins, resulting in a gravitational response. The interaction between amyloplasts and the tonoplast and their sedimentation through the central vacuole is an integral part of the transduction of the gravity signal in the mast statocyte. Decreased amyloplast sedimentation was observed in plant mutants with vacuole formation, transport via lesions (Kato et al., 2002; Morita et al., 2002), or endocytosis defects (Silady et al., 2004) and diminished stem gravitropism.

The histological analysis of cotyledons and true leave petioles was performed to identify mobile amyloplasts functioning as statoliths and performing a gravisensing function in the endoderm tissue of cress leave petioles (Fig. 4). The analysis showed that the lighting affects the number and size of the amyloplasts and the size of cells (Table 3). Upon illumination by UVA and UVA+BL, the number of true leaf petiole amyloplasts in the CR conditions was up to $10 \%$ higher and they were $5 \%$ larger in normal gravity $1 g$ conditions (Table 3 ).

Comparative leaf motion analysis showed that gravity essentially inhibits leaf phototropic reactions to UVA and UVA+BL. In MG conditions, such response of the leaves could have been caused by a stronger increase in the density of the photon flux of both UVA and BL. The results expand the understanding of the ecological functions of tropism and highlight the interactions between light and spectral components tropism. This phenomenon requires more comprehensive investigation. 


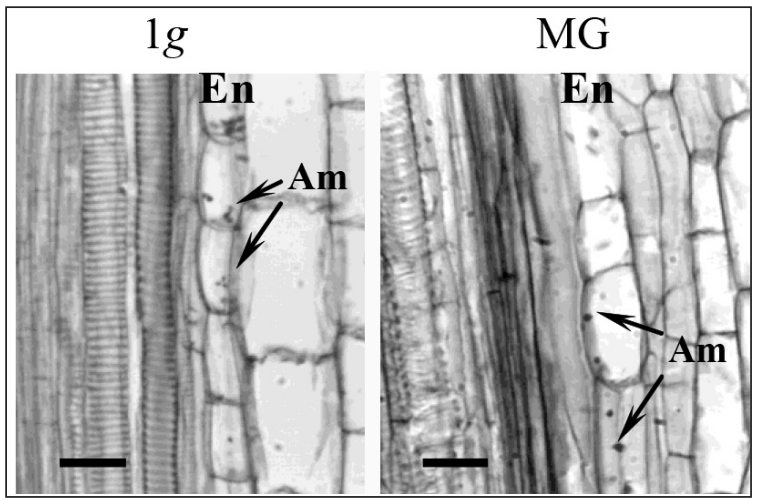

Fig. 4. Micrographs of longitudinal sections of leaf petiole. Garden cress leaves were illuminated with UVA and in clinorotation conditions on the slow clinostat and affected by normal gravity $(1 g)$. En - endoderm tissue cells; Am - amyloplasts. Bars - $20 \mu \mathrm{m}$

Table 3. The effect of UVA+BL lighting on the true leave stage of cress leaves petiole amyloplasts (their number and their size $(\mu \mathrm{m}))$ under clinorotation on the slow clinostat and affected by normal gravity $(1 g)^{*}$

\begin{tabular}{c|c|ccc}
\hline \multirow{2}{*}{ Illumination } & \multicolumn{2}{|c}{ Amiloplasts count in endodermal cells } & \multicolumn{2}{c}{ Amiloplasts diameter } \\
\cline { 2 - 5 } & $\mathbf{1} \boldsymbol{g}$ & $\mathbf{C R}$ & $\mathbf{1 g}$ & $\mathbf{C R}$ \\
\hline UVA & $7.90 \pm 0.04$ & $8.52 \pm 0.11^{*}$ & $1.72 \pm 0.02$ & $1.81 \pm 0.05^{*}$ \\
\hline UVA+BL & $8.61 \pm 0.08$ & $9.05 \pm 0.10^{*}$ & $2.01 \pm 0.05$ & $2.20 \pm 0.07^{*}$ \\
\hline
\end{tabular}

* - the difference between $1 g$ and CR variants is significant at $p \leq 0.05$.

\section{CONCLUSIONS}

UVA and clinorotation significantly inhibited leaf elongation and the area of true leaves compared to control plants. Clinorotation promoted a radial expansion and eliminated size differences in cotyledons under UVA and UVA+BL. UV radiation has a phototropic effect on leaves, which develops in microgravity. UVA+BL illumination had a slight positive effect on the leaves under normal gravity. The distribution of amyloplasts is dependent on gravity conditions. The combination of UVA radiation and the complex $\mathrm{UVA}+\mathrm{BL}$ under MG conditions promoted the formation of larger amyloplasts in true leaves. Upon illumination by UVA and UVA+BL, the number of true leaf petiole amyloplasts in the clinorotation conditions was higher and they were larger compared to normal gravity $(1 g)$ conditions.

\section{References}

1. Allen T, Ingles PJ, Praekelt U, Smith H, Whitelam GC. Phytochrome-mediated agravitropism in Arabidopsis hypocotyls requires GIL1 and confers a fitness advantage. Plant J. 2006; 46(4): 641-8.

2. Bastien R, Douady S, Moulla B. A unified model of shoot tropism in plants: photo-, gravi- and propio-ception. Plos Comput Biol. 2015; 11(2): 1-30.

3. Brazaitytė A, Jankauskienė J, Urbonavičiūtè A, Samuolienè G, Sirtautas R, Duchovskis P, Novičkovas A, Bliznikas Z, Žukauskas A. Pomidorų daigų auginimas, naudojant kietakūnius šviesos šaltinius. Sodininkystès ir daržininkystès mokslo tyrimai. 2010; 23: 105-11.

4. Brazaitytė A, Viršilè A, Jankauskienè J, Sakalauskienè S, Samuolienè G, Sirtautas R, Novičkovas A, Dabašinskas L, Miliauskiene J, Vaštakaitė $V$, Bagdonavičienè A, Duchovskis P. Effect of supplemental UV-A irradiation in solid-state lighting on the growth and 
phytochemical content of microgreens. Int Agrophys. 2015; 29: 13-22.

5. Buizer K. GraPhoBox: Gravitropism and phototropism in Arabidopsis thaliana. Microgravity Sci Technol. 2007; 19: 239-43.

6. Corell MJ, Kiss JZ. Interactions between gravitropism and phototropism in plants. Plant Growth Regul. 2002; 21: 89-101.

7. Fankhauser Ch, Chory J. Light control of plant development. Annu Rev Cell Dev Biol. 1997; 13: 203-29.

7. Friml J, Vieten A, Sauer M, Weijers D, Schwarz H, Hamann T, Offringa R, Jürgens G. Efflux-dependent auxin gradients establish the apical-basal axis of Arabidopsis. Nature. 2003; 426(6963): 147-53.

9. Hoson T, Kaminska S, Masuda Y, Yamashita M, Buchen B. Evaluation of the three-dimensional clinostat as a simulator of weightlessness. Planta. 1997; 203: 187-97.

10. Hua L, Cuia D, Neillb S, Caia W. OsEXPA4 and OsRWC3 are involved in asymmetric growth during gravitropic bending of rice leaf sheath bases. Physiol Plantarum. 2007; 130: 560-71.

11. Jayakumar M, Amudha P, Kulandaivelu G. Effect of low doses of UV-A and UV-B radiation on photosynthetic activities in Phaseolus mungo L. Plant Biology. 2004; 47(2): 105-10.

12. Jenkins GI. UV and blue light signal transduction in Arabidopsis. Plant Cell Environ. 1997; 20(6): 773-8.

13. Kato T, Morita M, Tasaka M. Role of endodermal cell vacuoles in shoot gravitropism. J Plant Growth Regul. 2002; 21: 113-9.

14. Kiss JZ, Millar KDL, Kumar P, Edelmann RE, Correll MJ. Improvements in the re-flight of spaceflight experiments on plant tropisms. Adv Space Res. 2011; 47: 545-52.

15. Kitaya Y, Kawai M, Tsuruyama J, Takahashi H, Tani A, Goto E, Saito T, Kiyota M. The effect of gravity on surface temperature and net photosynthetic rate of plant leaves. Adv Space Res. 2001; 28: 659-64.
16. Kittang AI, Van Loon JJ, Vorst O, Hall RD, Fossum K, Iversen TH. Ground based studies of gene expression in Arabidopsis exposure to gravity stresses. J Gravit Physiol. 2004; 11: 223-4.

17. Klem K, Gargallo-Garriga A, Rattanapichai W, Oravec M, Holub P, Vesela B, Sardans J, Penuelas J, Urban O. Distinct morphological, physiological, and biochemical responses to light quality in Barley leaves and roots. Front Plant Sci. 2019; 10: 1026.

18. Kordyum EL, Sobol M, Kalinina I, Bogadina N, Kondrachuk A. Cyclotron- based effect on plant gravitropism. Adv Space Res. 2007; 39: 1210-7.

19. Kraft TFB, Van Loon JJWA, Kiss JZ. Plastid position in Arabidopsis columella cells is similar in microgravity and on a random-positioning machine. Planta. 2000; 211: 415-22.

20. Krizek DT. Influence of PAR and UV-A in determining plant sensitivity and photomorphogenetic responses to UV-B radiation. Photochem Photobiol. 2004; 79(4): 307-15.

21. Kumar P, Kiss JZ. Modulation of phototropism by phytochrome $\mathrm{E}$ and attenuation of gravitropism by phytochromes $\mathrm{B}$ and $\mathrm{E}$ in inflorescence stems. Physiol Plant. 2006; 127: 304-11.

22. Kumar P, Montgomery CE, Kiss JZ. The role of phytochrome $\mathrm{C}$ in gravitropism and phototropism in Arabidopsis thaliana. Funct Plant Biol. 2008; 35(4): 298-305.

23. Lariguet P, Fankhauser C. Hypocotyl growth orientation in blue light is determined by phytochrome A inhibition of gravitropism and phototropin promotion of phototropism. Plant J. 2004; 40: 826-34.

24. Lariguet P, Fankhauser C. The effect of light and gravity on hypocotyl growth orientation. In: Wada M, Shimazaki K, Iino $M$, editors. Light sensing in plants. Springer-Verlag Tokyo Berlin Heidelberg New York. 2005; 277-84.

25. Laurinavičius R, Švegždienė D, Gaina V. Force sensivity of plant gravisensing. Adv Space Res. 2001; 5: 899-906. 
26. Maffei M, Canova D, Bertea CM, Scannerini S. UV-A effects on photomorphogenesis and essential-oil composition in Mentha piperita. J Photochem Photobiol. 1999; 52: 105-10.

27. Mano E, Horiguchi G, Tsukaya H. Gravitropism in leaves of Arabidopsis thaliana (L.) Heynh. Plant Cell Physiol. 2006; 47(2): 217-23.

28. Merkys A, Laurinavičius R. Plant growth in space. In: Asashima M, Malacinski GM, editors. Fundamentals of Space Biology. Japan Science Society Press, Tokyo, Springer-Verlag, Berlin. 1990; 69-83.

29. Millar KDL, Kumar P, Correll MJ, Mullen JL, Hangarter RP, Edelmann RE, Kiss JZ. A novel phototropic response to red light is revealed in microgravity. New Phytologist. 2010; 186(3): 648-56.

30. Millenaar FF, Cox MCH, De Jong van Berkel YEM, Welshen RAM, Pierik R, Voesenek LAC, Peeters AJM. Ethylene-induced differential growth of petioles in Arabidopsis. Analyzing natural variation, response kinetics, and regulation. Plant Physiology. 2005; 137(3): 998-1008.

31. Morita MT, Kato T, Nagafusa K, Saito C, Ueda T, Nakano A, Tasaka M. Involvement of the vacuoles of the endodermis in the early process of shoot gravitropism in Arabidopsis. Plant Cell. 2002; 14: 47-56.

32. Raklevičienè D, Losinska R, Švegždienè D. Clinorotation effect on response of cress leaves to red and far-red light. Microgravity Sci Technol. 2011; 23: 227-33.

33. Roychoudhry S, Kieffer M, Del Bianco M, Liao CheY, Weijers D, Kepinski S. The developmental and environmental regulation of gravitropic setpoint angle in Arabidopsis and bean. Sci Rep. 2017; 7: 42664.

34. Sarghein SH, Carapetian J, Khara J. Effects of UV-radiation on photosynthetic pigments and UV absorbing compounds in Capsicum longum (L.). Int J Bot. 2008; 4(4): 486-90.

35. Scherp P, Hasenstein H. Anisotropic viscosity of the Chara (Characeae) rhizoid cytoplasm. Am J Botany. 2007; 94(12): 1930-4.
36. Shinkle JR, Atkins AK, Humphrey EE, Rodgers CW, Wheeler SL, Barnes PW. Growth and morphological responses to different UV wavebands in cucumber (Cucumis sativum) and other dicotyledonous seedlings. Physiol Plant. 2004; 120: 240-8.

37. Silady RA, Kato T, Lukowitz W, Sieber P, Tasaka M, Somerville CR. The gravitropism defective 2 mutants of Arabidopsis are deficient in a protein implicated in endocytosis in Caenorhabditis elegans. Plant Physiol. 2004; 136: 3095-103.

38. Soh H, Auh C, Soh WY, Han K, Kim D, Lee S, Rhee Y. Gene expression changes in Arabidopsis seedlings during short- to long-term exposure to 3-D clinorotation. Planta. 2011; 234(2): 255-70.

39. Solheim BG, Johnsson A, Iversen TH. Ultradian rhytms in Arabidopsis thaliana leaves in microgravity. New Phytol. 2009; 183(4): 1043-52.

40. Stutte GW, Monje O, Hatfield RD, Paul AL, Ferl RJ, Simone CG. Microgravity effects on leaf morphology, cell structure, carbon metabolism and mRNA expression of dwarf wheat. Planta. 2006; 224: 1038-49.

41. Takemura K, Kamachi H, Kume A, Fujita T, Karahara I, Hanba TY. A hypergravity environment increases chloroplast size, photosynthesis, and plant growth in the moss Physcomitrella patens. J Plant Res. 2017; 130: 181-92.

42. Trewavas A. Green plants as intelligent organisms. Trends Plant Sci. 2005; 10: 414-9.

43. Urbonavičiūte A, Pinho P, Samuolienė G, Duchovskis P, Vitta P, Stonkus A, Tamulaitis G, Žukauskas A, Halonen L. Effect of short-wavelength light on lettuce growth and nutritional quality. Sodininkyste ir daržininkystè. 2007; 26(1): 157-65.

44. Urbonavičiūtė A, Samuolienė G, Brazaitytė A, Duchovskis P, Ruzgas V, Žukauskas A. The effect of variety and lighting quality on wheatgrass antioxidant properties. ZemdirbysteAgriculture. 2009; 96(3): 119-28. 
45. Victório CP, Leal-Costa MV, Tavares ES, Kuster RM, Lage CL. Effects of supplemental UV-A on the development, anatomy and metabolite production of Phyllanthus tenellus cultured in vitro. Photochem Photobiol. 2011; 87(3): 685-9.

46. Vitha S, Yang M, Sack FD, Kiss JZ. Gravitropism in the starch excess mutant of Arabidopsis thaliana. Am J Botany. 2007; 94(4): 5908.

47. Vitha S, Zhao L, Sack FD. Interaction of root gravitropism and phototropism in Arabidopsis of wild-type and starchless mutants. Plant Physiol. 2000; 122: 453-61.

48. Whippo CW, Hangarter RP. Phytochrome modulation of blue-light-induced phototropism. Plant Cell Environ. 2004; 27: 1223-8.

49. Yamamoto K, Kiss JZ. Disruption of the actin cytoskeleton results in the promotion of gravitropism in inflorescence stems and hypocotyls of Arabidopsis. J Plant Physiol. 2002; 128: 669-81.

\section{Regina Losinska-Sičiūnienè, Ramunẻ Stanevičienė, Danguolè Švegždienė \\ ULTRAVIOLETO A IR JO DERINIO SU MĖLYNA ŠVIESA POVEIKIS SĖJAMOSIOS PIPIRNĖS LAPỤ FOTOTROPINEI REAKCIJAI IR AUGIMUI İVAIRIOMIS GRAVITACIJOS SĄLYGOMIS}

\section{Santrauka}

Gravitacija ir šviesa - tai du svarbiausi fiziniai aplinkos veiksniai. Pirmasis Žemèje kinta mažiausiai, o antrasis kinta nuolat. Šių veiksnių įtaka augalų erdvinei orientacijai, augimui, vystymuisi ir produktyvumui yra neabejotina. Mèlyna spektro komponentė stipriau negu UV-A valdo skilčialapių ir tikrųjų lapų sejjamosios pipirnès (Lepidium sativum L.) tropinio augimo procesus iprastinès gravitacijos (1g) sąlygomis. Diferencijuotas UV-A ir kompleksinis UV-A su mèlyna šviesa apšvietimo poveikis lapų augimui MG sąlygomis priklauso nuo organų išsivystymo fazès (skilčialapiai ar tikrieji lapai). Nustatyta, kad gravitacija ( $1 g$ ) slopina UV-A ir UV-A su mèlyna šviesa poveikị lapų fototropizmui. MG sąlygomis UV-A spinduliuotė sukelia teigiamą lapų fototropinę reakciją, o kompleksinis apšvietimas UV-A su mèlyna spektro komponente - tikrųjų lapų neigiamą fototropinę reakciją ir reakcijos lètėjimą, priešingai nei $1 g$ aplinkoje. Nustatyta, kad sèjamosios pipirnès lapų lapkočių gravisensoriniame audinyje amiloplastai funkcionuoja kaip statolitai ir atlieka gravisensorių funkciją. Amiloplastų viduląstelinis išsidèstymas priklauso nuo gravitacijos sąlygų. Tačiau UV-A spinduliuotés ir UV-A su mèlyna šviesa derinys MG sąlygomis skatino amiloplastų tikrųjų lapų lapkočiuose formavimąsi.

Raktažodžiai: gravitacija, klinostatavimas, ultravioletas $\mathrm{A}$, lapai, tropizmai 